\title{
Kanserin Ayırt Edici Özelliklerinde Kodlanmayan RNA'Iarın Rolü: Güncel Bir Bakış
}

\section{The Role of Non-coding RNAs in the Hallmarks of Cancer: A Current Perspective}

Esra Bozgeyik ${ }^{1}$

${ }^{1}$ Tekirdağ Namık Kemal Üniversitesi, Tıp Fakültesi, Tıbbi Biyoloji Anabilim Dalı, Tekirdağ, Türkiye

Geliş Tarihi/Received: 2 Nisan 2019 Kabul Tarihi/Accepted: 6 Ekim 2019

Yazışma Adresi: Esra Bozgeyik, Tekirdağ Namık Kemal Üniversitesi, Tıp Fakültesi Tıbbi Biyoloji Anabilim Dalı, Tekirdağ, Türkiye e-mail: gyk.esra@gmail.com

\section{ORCID}

Esra Bozgeyik

https://orcid.org/0000-0002-8726-3182

\begin{abstract}
Öz
Kanser, genomda meydana gelen bir seri bozukluklar sonucu ortaya çıkan ciddi bir genetik hastalıktır. Yüksek verimli yeni nesil dizileme teknolojilerinin geliştirilmesi ve büyük ölçekli projelerin verilerinin yayınlanması farklı kanser türlerinde değişik ifade profili gösteren birçok kodlanmayan RNA (ncRNA) molekülünün tespit edilmesine olanak sağlamıştır. Uzun kodlanmayan RNA (IncRNA) ve mikroRNA (miRNA) gibi ncRNA transkriptlerinin kanserin oluşumunda ve ilerlemesinde kritik rollerinin olduğu ve kanser tanısında/tedavisinde kullanılabilir olduğu bildirilmiştir. Özellikle, miRNA'lar gen ifadesini posttranskripsiyonel seviyede kontrol eden ve kanserin önemli ayırt edici özellikleri olan metastaz, invazyon, hücre çoğalması, farklılaşması, anjiyogenez gibi önemli süreçlerde kritik rolleri olduğu bilinen küçük RNA molekülleridir. Benzer şekilde, IncRNA'lar da kanserin moleküler mekanizmasının aydınlatılmasında önemli yeri olan RNA transkriptleri olarak tanımlanmışlardır. Dolayısıyla, bu kapsamlı derlemede miRNA, IncRNA, T-UCR gibi protein kodlama kapasitesi olmayan ancak işlevsel olan ncRNA'lar ile kanserin ayırt edici özellikleri güncel bir bakış açısı ile ele alınmıştır.
\end{abstract}

Anahtar Kelimeler: Kanser, Kanserin Ayırt Edici Özellikleri, Kodlanmayan RNA'lar, LncRNA, miRNA, ncRNA.

\begin{abstract}
Cancer is a serious genetic disease caused by a series of disorders in the genome. Development of high-troughput sequencing approaches as well as the publication of large-scale projects have enabled the identification of several non-coding RNA molecules that are differentially expressed in various types of cancer. It has been reported that ncRNA transcripts such as long non-coding RNAs (IncRNAs) and microRNAs (miRNAs) have critical roles in the development and progression of cancer and can be used in the diagnosis/treatment of cancer. In particular, miRNAs are small RNA molecules which control gene expression at the post-transcriptional level and play critical roles in the important hallmark capabilities of cancers such as metastasis, invasion, cell proliferation, differentiation, and angiogenesis. Similarly, IncRNAs have also been identified as RNA transcripts that have important roles in the understanding of the molecular mechanism of cancer. Accordingly, in this comprehensive review, functional ncRNA molecules without protein coding capacity such as miRNAs, IncRNAs, and T-UCRs and the hallmarks of cancer were discussed together with a current perspective.
\end{abstract}

Key words: Cancer, Hallmarks of cancer, Non-coding RNAs, LncRNA, miRNA, ncRNA
Atıf yapmak için: Bozgeyik E. Kanserin Ayırt Edici Özelliklerine Güncel Bakış. Selcuk Med J 2020;36(4): 381-396 Açıklama: Yazar bu makalede bahsedilen herhangi bir ürün, aygıt veya
ilaç ile ilgili maddi çıkar ilişkisine sahip değildir. Araştırma, herhangi bir dış̧
organizasyon tarafından desteklenmedi. Yazar çalışmanın birincil verilerine
tam erişim izni vermek ve derginin talep ettiği takdirde verileri incelemesine
izin vermeyi kabul etmektedir. 


\section{GíRiş}

Insan Genom Projesi, ENCODE (Encyclopedia of DNA Elements) projesi gibi geniş ölçekli projeler yayımlandığında genomun yalnızca \%2'lik bir kısmını protein kodlayan genlerin oluşturduğu görülmüştür $(1,2)$. Kalan \% 98'lik kısım kodlanmayan RNA'ların keşfedilmesinden önce "çöp", "genomik atık" ve "transkripsiyonel parazit" gibi isimler ile anılmıştır. Kodlanmayan RNA'ların keşfi ile birlikte geri kalan kısmın genomik atıktan ziyade büyük oranda işlevsel RNA moleküllerini kodladığı ortaya konulmuştur. Bu transkriptler protein kodlama potansiyeli olmayan, fakat hücre içerisinde birçok sinyal yolağının uyarılmasında ve/veya baskılanmasında aktif görev alan moleküllerdir. Dahası, bu işlevsel RNA moleküllerinin protein kodlayan genleri ve diğer RNA genlerini de post-transkripsiyonel seviyede pozitif/ negatif yönlü olarak düzenlediği rapor edilmiştir. Aslında protein sentezinde görevli olan ribozomal RNA (rRNA), taşıyıcı RNA (tRNA), küçük nükleer RNA (snRNA) ve küçük nükleolar RNA (snoRNA) gibi ncRNA'ların varlığı uzun yıllardır bilinmektedir. Ancak güncel gelişmeler, ncRNA'ların tRNA'lar, rRNA'lar, snRNA'lar ve snoRNA'lar ile sınırlı olmadığını göstermiştir (3).

NcRNA'ların birçok farklı alt sınıfı bulunmaktadır. Ancak, bir ncRNA molekülü fonksiyonu, genomdaki ve hücre içindeki yerleşimi, hücresel süreçlerdeki etkinliği ve ifade seviyelerindeki değişimine göre birden fazla gruba dâhil edilebilmektedir. Dolayısıyla, kodlanmayan RNA'ları tek bir kritere göre kategorize etmek mümkün değildir. Ancak, klasik olarak bazı alt sınıflara ayrılmışlardır. NcRNA'lar uzunluklarına göre kısa ncRNA'lar (<200nt) ve uzun ncRNA'lar (>200 nt)

Tablo 1. Kanserin ayırt edici özelliklerinde rol oynayan miRNA'lar

\begin{tabular}{|c|c|c|c|}
\hline Ayırt edici özellik & miRNA & Hedeflediği gen(ler) & Kaynak \\
\hline \multirow[t]{5}{*}{ Çoğalma Uyarısının Devamlılığı } & $\begin{array}{l}\text { miR-145-5p, } \\
\text { miR-34c, miR-29a-3p, }\end{array}$ & CDK4/CDK6 & $(10-12)$ \\
\hline & miR-142-3p, miR-24-3p & CDK4 & (13) \\
\hline & $\begin{array}{l}\text { let- } 7 a-5 p \text {, let- } 7 b-5 p \\
\text { miR-16-5p }\end{array}$ & CDK6 & $(14-15)$ \\
\hline & miR-218-5p & EGFR & (19) \\
\hline & miR-342-3p & EGFR, BCL2 & (21) \\
\hline \multirow[t]{3}{*}{ Büyüme Baskılayıcılarından Kaçış } & $m i R-497-5 p$ & circPVT1 & (32) \\
\hline & miR-34a & SIRT1 & (35) \\
\hline & miR-199a & ANRIL & (36) \\
\hline \multirow[t]{4}{*}{ Hücre Ölümüne Karşı Direnç } & miR15a, miR-16 & BCL2 & $(40)$ \\
\hline & miR-206, miR-1290 & BCL2 & (41) \\
\hline & miR-206 & MET & (42) \\
\hline & miR-143-3p & HOTAIR & (43) \\
\hline Ölümsüz Çoğalmaya Olanak Sağlama & $\begin{array}{l}\operatorname{miR}-155, \operatorname{miR}-138 \\
\operatorname{miR}-34 a, b, c\end{array}$ & TRF1 & $(48)$ \\
\hline Anjiyogenezin Tetiklenmesi & $\begin{array}{l}\text { miR-103b, miR-330a-5p, } \\
\text { miR-557, miR-575, } \\
\text { miR-1287-5p, miR-1468-5p }\end{array}$ & ANG1, ANG2 & $(53)$ \\
\hline \multirow[t]{3}{*}{ İnvazyon ve Metastazın Etkinleşmesi } & $\mathrm{miR}-200 \mathrm{c} / \mathrm{b}$ & ZEB1/2 & (59) \\
\hline & miR-200 & E-cadherin & (59) \\
\hline & miR-23b-3p & HOTAIR, ZEB1 & (61) \\
\hline \multirow[t]{3}{*}{ Genom Kararsızlığı ve Mutasyon } & miR-29 & $\mathrm{PIK} 3 \mathrm{R} 1, \mathrm{CDC} 42$ & $(65,66)$ \\
\hline & $\operatorname{miR}-122$ & CCND1 & $(65,66)$ \\
\hline & miR-335, miR-708-5p & PARP1 & $(67,68)$ \\
\hline $\begin{array}{l}\text { Tümör Oluşumunu Teşvik } \\
\text { Eden Inflamasyon }\end{array}$ & miR-155 & JAK/STAT1 & (71) \\
\hline \multicolumn{4}{|l|}{ Enerji Programının } \\
\hline \multirow[t]{3}{*}{ Yeniden Düzenlenmesi } & miR-497 & HK2 & $(74)$ \\
\hline & miR-520 & TARDBP & (75) \\
\hline & miR-133a, miR-133b & PKM2 & (76) \\
\hline \multirow[t]{2}{*}{ Bağışıklık Sisteminden Kaçış } & miR-155 & IFN-y & (78) \\
\hline & miR-448 & SNHG1 & $(80)$ \\
\hline
\end{tabular}


olmak üzere iki ana alt sınıfa ayrılmıştır. Bu sınıflar da kendi içerisinde bazı alt gruplara ayrılmaktadır $(4,5)$. Küçük kodlanmayan RNA'lar miRNA, küçük müdahaleci RNA (siRNA), küçük nükleer RNA (snRNA) ve küçük nükleolar RNA (snoRNA) ve PIWI etkileşimli RNA (piRNA) olarak farklı alt sınıflara ayrılabilmektedir. Küçük kodlanmayan RNA'ların en yaygın olarak bilinen üyesi miRNA'lardır. Genellikle 22 nt uzunluğundaki işlevsel moleküller olan miRNA'lar hedeflediği genleri post-transkripsiyonel seviyede düzenleyip apoptoz, hücre döngüsü ve farklılaşması gibi kritik hücresel süreçlerde anahtar rol oynarlar. miRNA'lar bu düzenlemeyi hedeflediği genin translasyona çevrilmeyen kısmı (untranslated region, UTR) ile kısmi tamamlayıcılık (complementarity) göstererek gerçekleştirmektedir (4). Bu derleme kapsamında, kanser sürecinde etkili olan miRNA'lar Tablo 1'de gösterilmiştir.

Uzun kodlanmayan RNA (ncRNA)'lar ise geniş spektrumlu fonksiyonlarından dolayı büyük bir heterojen RNA grubunu oluşturmaktadırlar. Büyük RNA (large RNA), makro RNA ve uzun intergenik RNA (lincRNA) olarak da bilinen IncRNA'lar protein kodlayan ve kodlamayan genlerin arasında yerleşik RNA genleri tarafından transkripte edilmektedir (5). LncRNA'lar genomdaki yerleşimlerine göre uzun intergenik RNA (lincRNA), antisense RNA (asRNA), intronik RNA, sense RNA (sRNA), aşırı korunmuş bölge transkriptleri (ultra-conserved genomic region, T-UCR), promotör ilişkili RNA (PARP), arttırıcı RNA (enhancer RNA, eRNA) gibi farklı alt kategorilere ayrılabilmektedir. NcRNA'lar ile ilişkili olarak bugüne kadar elde edilen veriler işlevsel olan bu moleküllerin kanserin de içerisinde olduğu birçok hastalığın patogenezinde önemli rollerinin olduğunu kanıtlar niteliktedir. Ayrıca, ncRNA'ların, kromatin modifikasyonu, transkripsiyon ve transkripsiyon sonrasındaki süreçlerde gen ifadesini birçok yönden etkileyerek önemli görevler üstlendiği aşikârdır. Kanserin ayırt edici özelliklerinde etkili olan IncRNA'lar Tablo 2'de gösterilmiştir.

Hanahan ve Weinberg 2000 yılında insan kanserlerinin çok aşamalı gelişim sürecinde kazandığı çoğalma uyarısının devamlılığı, büyümeyi baskılayan faktörlerden kaçış, hücre ölümüne karşı direnç, ölümsüz çoğalmaya olanak sağlama, anjiyogenezin tetiklenmesi ve invazyon ve metastazın aktifleşmesi şeklinde sıralanan altı ana ayırtedici özelliğin olduğunu ortaya koymuşlardır. Daha sonra yayınladıkları güncelleme makalesinde bu ayırt edici özelliklere ek olarak enerji programının yeniden düzenlenmesi, bağışıklık sisteminden kaçış, genom kararsızlığı ve mutasyon ve tümör oluşumunu destekleyen inflamasyon olmak üzere dört yeni özelliğin olduğunu bildirmişlerdir $(6,7)$.

Protein kodlayan genlere benzer şekilde ncRNA'lar hemen hemen tüm insan kanserlerinde düzensiz ifade edildiklerinden dolayı kanserin ayırt edici özelliklerinin her birinde önemli rol oynarlar. Dolayısıyla bu derlemede, protein kodlayan genlere ek olarak kanser oluşumu ve gelişimine katkıda bulunan miRNA'lar ve uzun IncRNA'lar ışığında kanserin ayırt edici özelliklerine güncel bir bakış açısı getirmeyi amaçladık. Her bir ayırt edici özellikte rol oynayan ana protein kodlayan genlerin yanı sıra bunları hedef alan miRNA ve diğer kodlanmayan RNA'lardan bahsetmeye çalıştık.

\section{Çoğalma Uyarısının Devamlıı̆̆ı}

Şüphesiz çoğalma uyarısının devamlılığı kanserin ayırt edici özellikleri arasında en baş sıralarda yer almaktadır. Normal dokular, hücre büyümebölünme döngüsüne giriş ve ilerlemeyi kontrol etmek amacıyla büyümeyi teşvik eden sinyallerin üretimini ve salınımını dikkatli bir şekilde kontrol ederler (7). Böylece, hücre sayısı ve dolayısıyla normal doku bütünlüğünün ve fonksiyonunun muhafaza edilmesini sağlanmış olur (7).

Birçok gen ve protein, özellikle kinazlar ve kinaz reseptörleri, bu süreçlerde aktif rol almaktadırlar. Dolayısıyla kinazlar ve kinaz reseptörleri potansiyel tedaviye yönelik hedefler olarak kanser tedavisinde halen çok ilgi çekmektedirler. Hücre çoğalması için son derece önemli olan bir protein kinaz ailesi olan siklin bağımlı kinazlar (CDK'ler), hücre döngüsü boyunca ilerlemeyi düzenlerler. Yer aldıkları yolaklar genellikle insan kanserlerinde düzensizdir ve bu durum hücre döngüsünün gerekli kontrol noktalarında durmayıp ilerlemesine, dolayısıyla kontrolsüz hücre çoğalmasına yol açar (8). Özellikle siklin D tarafından aktive edilen ve hücre döngüsünün $\mathrm{G} 1$ fazı boyunca ilerlemesi için önemli olan CDK4 ve CDK6, kanser tedavisinde popüler hedefler haline gelmişlerdir. Özgül CDK4/6 baskılayıcıları olan ribociclib ve palbociclib son zamanlarda birkaç insan kanseri tedavisi için FDA (Food and Drug Administration) tarafindan onaylanmıştır (9). Ayrıca, kodlanmayan RNA'ların CDK4 ve CDK6 gibi hücre döngüsünde önemli roller oynayan proteinleri hedefleyerek çoğalma uyarısını devamlılığına ve büyüme baskılayıcılardan kaçış özelliklerine katkıda bulunduğu görülmektedir. CDK4 ve CDK6, birçoğu her iki CDK'yı hedef alan miR-145$5 p$ (10), miR-34c (11) ve miR-29a-3p (12) gibi çeşitli 
Tablo 2. Kanserin ayırt edici özelliklerinde rol oynayan IncRNA'lar

\begin{tabular}{|c|c|c|c|c|}
\hline Ayırt edici özellik & LncRNA & Açık adı & Kanser çeşidi & Kaynak \\
\hline \multirow[t]{5}{*}{ Çoğalma Uyarısının Devamlılığı } & MALAT1 & $\begin{array}{l}\text { Metastasis-associated } \\
\text { lung adenocarcinoma } \\
\text { transcript } 1\end{array}$ & Meme kanseri & $(16)$ \\
\hline & NEAT1 & $\begin{array}{l}\text { Nuclear paraspeckle } \\
\text { assembly transcript } 1\end{array}$ & Glioma & $(17)$ \\
\hline & EGFR-AS1 & EGFR antisense 1) & Mide kanseri & (22) \\
\hline & FER1L4 & $\begin{array}{l}\text { Fer- } 1 \text { - like family } \\
\text { member } 4\end{array}$ & Hepatosellüler kanser & (29) \\
\hline & Uc. 160 & Ultraconserved 160 & Mide kanseri & (31) \\
\hline \multirow{4}{*}{ Büyüme Baskılayıcılarından Kaçış } & circPVT1 & circular RNA PVT1 & HNSCC & (32) \\
\hline & uc.339 & Ultraconserved 339 & NSCLC & (33) \\
\hline & ANRIL & $\begin{array}{l}\text { Antisense non-coding } \\
\text { RNA in the INK4 locus }\end{array}$ & Meme kanseri, Glioma & $(34)$ \\
\hline & GAS5 & Growth Arrest-Specific 5 & Lösemi & $(36)$ \\
\hline \multirow[t]{2}{*}{ Hücre Ölümüne Karşı Direnç } & HOTAIR & $\begin{array}{l}\text { HOX transcript } \\
\text { antisense RNA }\end{array}$ & Meme kanseri & $(43)$ \\
\hline & PANDA & $\begin{array}{l}\text { P21 associated ncRNA } \\
\text { DNA damage activated }\end{array}$ & Meme kanseri & $(44)$ \\
\hline Ölümsüz Çoğalmaya & TERC & \multicolumn{2}{|l|}{ Telomerase RNA Component } & (46) \\
\hline Olanak Sağlama & TERRA & \multicolumn{2}{|c|}{ Telomeric repeat-containing RNA } & (47) \\
\hline Anjiyogenezin Tetiklenmesi & aHIF1 & $\begin{array}{l}\text { Hypoxia inducible factor } \alpha \\
\text { antisense transcript }\end{array}$ & Renal karsinom & $(54)$ \\
\hline İnvazyon ve Metastazın & HULC & $\begin{array}{l}\text { Highly up-regulated in } \\
\text { liver cancer }\end{array}$ & Hepatosellüler kanser & $(60)$ \\
\hline Etkinleşmesi & $\begin{array}{l}\text { HOTAIR } \\
\text { MALAT1 }\end{array}$ & $\begin{array}{l}\text { HOX transcript antisense RNA } \\
\text { Metastasis-associated lung } \\
\text { adenocarcinoma transcript } 1\end{array}$ & $\begin{array}{l}\text { Hepatosellüler kanser } \\
\text { NSCLC }\end{array}$ & $\begin{array}{l}(61) \\
(62)\end{array}$ \\
\hline $\begin{array}{l}\text { Genom Kararsızlığı ve } \\
\text { Mutasyon }\end{array}$ & NORAD & $\begin{array}{l}\text { noncoding RNA activated by } \\
\text { DNA damage }\end{array}$ & Kolon kanseri & $(70)$ \\
\hline \multirow[t]{2}{*}{$\begin{array}{l}\text { Enerji Programının } \\
\text { Yeniden Düzenlenmesi }\end{array}$} & PVT1 & $\begin{array}{l}\text { Plasmacytoma Variant } \\
\text { Translocation } 1\end{array}$ & Osteosarkom & $(74)$ \\
\hline & LincRNA-p21 & LincRNA-p21 & Serviks, meme kanseri & (77) \\
\hline \multirow[t]{2}{*}{ Bağışıklık Sisteminden Kaçış } & HULC & $\begin{array}{l}\text { Highly up-regulated in } \\
\text { liver cancer }\end{array}$ & Hepatosellüler kanser & (79) \\
\hline & SNHG1 & $\begin{array}{l}\text { Small nucleolar RNA } \\
\text { host gene1 }\end{array}$ & Meme kanseri & $(80)$ \\
\hline
\end{tabular}

miRNA'lar tarafından doğrudan düzenlenebilmektedir. Ayrıca, her bir CDK'yı hedefleyen farklı miRNA'ların olduğu da gösterilmiştir. Örneğin miR-142-3p (13) ve miR-24-3p gibi miRNA'lar yalnızca CDK4'ü düzenlerken, CDK6 doğrudan let-7a-5p, let-7b-5p (14) ve miR-16-5p (15) gibi miRNA'lar tarafından düzenlenebilmektedir. Aynı zamanda, birçok IncRNA molekülünün de hücre döngüsünün kontrolünü sağladığı gösterilmiştir. MALAT1 (metastasisassociated lung adenocarcinoma transcript 1)'in, meme kanserinde miR-124'ün hücre çoğalması üzerindeki baskılayıcı etkisini negatif yönde düzenleyerek ve CDK4/E2F1 yolağında yer alarak hücre çoğalmasının uyarılmasına aracılık ettiği gösterilmiştir (16). Buna ek olarak, NEAT1 (nuclear paraspeckle assembly transcript 1) geninde meydana gelen delesyonun miR106-CDK6 yolağını etkileyerek glioma hücrelerinin kök hücre-benzeri özelliğinin baskılanmasına neden olduğu gösterilmiştir (Şekil 1) (17).

Ayrıca, büyüme faktörü reseptör seviyesinde ve reseptör sinyal iletiminde meydana gelen değişimler hücrelerin büyüme faktörlerine daha duyarlı hale gelmesine neden olarak çoğalma uyarısının devamlılığını sağlayabilir (7). Büyüme faktörü reseptör seviyesinde meydana gelen artış, reseptörün sınırlı seviyedeki büyüme faktörü ligandına karşı aşırı duyarlı hale gelmesine neden olabilir. Benzer şekilde reseptör moleküllerinde meydana gelen yapısal bozukluklar da liganddan bağımsız bir şekilde reseptörün sürekli olarak sinyal göndermesine neden olabilir ve dolayısıyla çoğalma uyarısının devamlılığını 


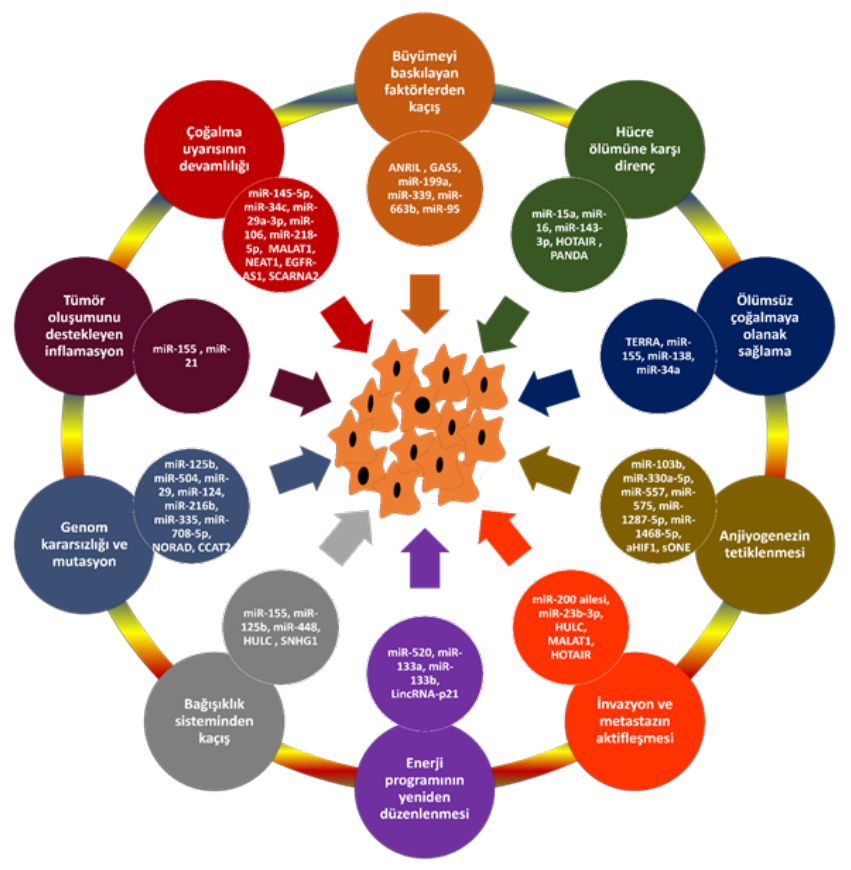

Şekil 1. Kanserin ayırt edici özellikleri ve her ayırt edici özellikte rol oynayan kodlanmayan RNA'ların gösterilmesi.

sağlayabilir (7). Büyüme faktöründen bağımsız olarak sinyal iletimi, büyüme faktörü reseptörlerinin aşağı (downstream) sinyal yolağı bileşenlerinin yapısal aktivasyonundan da kaynaklanabilir. Bu durum ligand aracılı reseptör aktivasyonu ile bu yolakların uyarılma gereksinimini ortadan kaldırır (18). Epidermal büyüme faktörü reseptörü (EGFR), ligandı olan epidermal büyüme faktörünün (EGF) bağlanmasıyla aktive edilen bir reseptör tirozin kinazdır. Ligand bağlanması reseptör dimerizasyonu ve otofosforilasyona yol açarak çoğalmayı destekleyen sinyal ileti yolaklarının aktivasyonu ile sonuçlanır. Kanserde, EGFR'nin düzensizliği aşırı ifade edilme, çoğalma ve EGFR mutasyonu ile gerçekleşir ve bu durum onu tedaviye yönelik ilginç bir hedef haline getirir. Birçok EGFR baskılayıcısı kanser tedavisinde kullanılmak üzere FDA tarafından onaylanmıştır. EGFR hücre içerisinde birçok ncRNA tarafından düzenlenmektedir. Örneğin; miR-218-5p'nin PI3K/Akt/mTOR yolağı aracılığıyla EGFR'nin ifade seviyesini önemli ölçüde baskıladığı gösterilmiştir (19). Buna ek olarak, miR-141 kanser hücrelerinde EGFR'yi hedefleyerek ve EGFR'nin alt sinyal yolağındaki proteinleri etkileyerek hücre büyümesini ve metastazını baskıladığı gösterilmiştir (20). Aynı zamanda, small Cajal body-specific RNA 2 (SCARNA2)'nin kanser hücrelerinde EGFR ve
B-hücresi lenfoma 2 (BCL2) ifadesini kolaylaştırmak için rekabetçi şekilde bağlanan miR-342-3p üzerinden kemoterapi direncini arttırdığı gösterilmiştir (21). Ayrıca, EGFR geninin karşı sarmalından sentezlenen ve EGFR ile arasında 194 bp uzunluğunda baz eşleşmesi bulunan EGFR-AS1 (EGFR antisense 1)'nin EGFR'nin mRNA kararlılığını etkileyerek ifade seviyesinin azalmasına neden olduğu bildirilmiştir (22).

Kanserli hücre genomlarının yüksek verimli DNA dizileme analizleri, bazı insan tümörlerinde genellikle büyüme faktörleri ile tetiklenen sinyal yolaklarının yapısal aktivasyonunu öngören somatik mutasyonları ortaya çıkarmıştır. Örneğin; B-Raf proteinin yapısal olarak aktifleşmesi Raf proteininden mitojenle aktive olan protein (MAP)-kinaz yolağına sürekli sinyal iletimine neden olarak çoğalma uyarısını devamlılığını sağlar. İnsan melanomlarının \% 40'ında B-Raf proteininin yapısını etkileyen aktive edici mutasyonlar saptanmıştır (23). Benzer şekilde birçok insan tümöründe phosphoinositide-3 kinaz izoformlarının katalitik alt birimlerinde mutasyonlar tespit edilmiştir. Bu mutasyonlar PI3-kinaz aracılı sinyal iletiminin aşırı aktifleşmesine sebep olmakta ve çoğalma uyarısının devamlıı̆̆ını sağlamaktadır (24).

MAPK kanser tedavisinde tedaviye yönelik hedef haline gelmiş hücre çoğalmasında önemli rolleri olan diğer bir kinaz ailesidir. Yapılan araştırmalar miR-34a5p (25) ve miR-1826 (26) gibi miRNA moleküllerinin MAP2K1 hedefleyerek hücre çoğalmasına etki ettiğini göstermiştir. Buna ek olarak, serviks kanserinde miR-99b'nin PI3K/AKT/mTOR sinyal yolağını baskılayarak hücre çoğalmasını baskıladığı, hücre döngüsüne girişi engellediği ve apoptozu uyardığı gösterilmiştir (27). Benzer olarak, MALAT1'in miR22-3p tarafından hedeflenerek PI3K/AKT yolağını baskılayarak kanser hücrelerinin çoğalmasını ve göçünü etkilediği gösterilmiştir (28). Diğer bir IncRNA molekülü FER1L4'ün (Fer- 1- like family member 4) kanserde aşırı ifade edilmesi, PI3K/AKT yolağının düzenlenmesiyle hücre çoğalması ve göçünü baskılamıştır (29).

Geri-besleme mekanizmasında meydana gelen bozuklukların da çoğalma uyarısının devamılılığına önemli derecede katkıda bulunduğu ortaya konulmuştur (35-37). Ras proto-onkoproteininin geri-besleme mekanizmasında meydana gelen bozukluklar bu duruma en iyi örnektir. Normal koşullarda Ras proteni GTPaz aktivitesi ile kendi kendini etkisiz konuma getirebilmektedir. Dolayısıyla, bu proteinin GTPaz aktivitesinin bozulmasına neden 
olan mutasyonlar, Ras proteinin kendi kendini etkinsizleştirmesine engel olmakta ve sinyal iletiminin sürekli hale gelmesine neden olmaktadır (30). PTEN geninde meydana gelen fonksiyon kaybı mutasyonları bu duruma diğer bir örnektir. PTEN fosfotaz, PI3kinazın ürünü olan fosfatidilinositol $(3,4,5)$ trisfosfat (PIP3)'ı yıkarak PI3-kinazın aktivitesine karşı etki gösterir. PTEN'deki fonksiyon kaybı mutasyonları, çeşitli deneysel kanser modellerinde ve insan tümörlerinde PI3K sinyal iletimini güçlendirerek tümör oluşumunu teşvik ettiği ortaya konulmuştur (24).

Birçok malignitelerinin oluşumunda ve ilerlemesinde önemli fonksiyonları olan T-UCR'ler bir IncRNA sınıfı üyesidir. Uc.160'ın kanser gelişiminde baskılayıcı işlev gösterdiği bildirilmiştir. Uc.160, mide kanserinde PTEN'nin ifade seviyesini arttırarak Akt'in fosforilasyonunu baskıladığı bulunmuştur (31). Ayrıca, uc.160'ın arttırılması MAPK sinyalinin baskılanmasına neden olan PTEN seviyesini de arttırarak kanserde tümör baskılayıcı özellik göstermiştir (31).

\section{Büyüme Baskılayıcılarından Kaçış}

Kanserin diğer bir önemli ayırt özelliği ise hücre büyümesini ve çoğalmasını baskılayıcı mekanizmalardan kaçmalarıdır (7). Dolayısıyla, kanser hücreleri çoğalmayı sürdürebilmek için birçok mekanizma geliştirmişlerdir. Bu mekanizmaların birçoğu tümör baskılayıcı genlerin etkilerine bağlıdır (7). Hücre büyümesini ve çoğalmasını sınırlandırmak için çeşitli şekillerde faaliyet gösteren düzinelerce tümör baskılayıcı protein, hayvan ya da insan kanserlerinde etkilerini kaybetmeleri ile keşfedilmiştir. Bilinen en önemli tümör baskılayıcı proteinlerden ikisi Rb (retinoblastoma-associated) ve p53 (Tumor Protein 53)'tür. Bu iki proteinin fonksiyonunda meydana gelen bozukluklar hücre döngüsü kontrolünün kaybına neden olmakta ve kanserleşme sürecine önemli derecede katkıda bulunmaktadır. Rb proteini, çeşitli hücre dışı ve hücre içi kaynaklardan gelen sinyalleri bütünleştirir ve bir hücrenin büyümebölünme döngüsü boyunca ilerlemesi gerekip gerekmediğine karar verir. RB geninde meydana gelen mutasyonlar bu proteinin fonksiyonunu yerine getirememesine sebep olmakta ve dolayısıyla RB aracılı hücre döngüsü kontrolünün kaybına sebep olmaktadır. RB, büyük oranda hücre dışı büyümeyi önleyici sinyallere karşı fonksiyon gösterirken, TP53, hücre içi işletim sistemlerinde fonksiyon gösteren stres ve anormallik sensörleri tarafından uyarılır. Eğer genomda meydana gelen hasar fazla ise ya da hücrede nükleotid seviyeleri, büyümeyi teşvik eden faktörler, glikoz ve oksijenasyon normal seviyelerde değilse TP53 hücre döngüsünün ilerlemesini tüm bu koşullar normalleşene kadar duraklatır. Alternatif olarak, hücresel sistemlerin şiddetli ve onarılamaz derecede hasarlı olduğu durumlarda TP53 apoptozu tetikleyebilir.

Ökaryot hücrelerdeki endojen RNA molekülleri TP53 ve RB1 genlerini düzenleyerek kanser hücrelerinde büyümeyi kontrol etmede aracılık edebilirler. Örneğin halkasal RNA circPVT1 baş ve boyun skuamöz hücreli karsinomda (HNSCC), hücre çoğalmasının kontrolünü sağlayan genleri ve miR-4975p'nin ifade seviyesini modüle ederek onkogenik işlev gösteren bir ncRNA olarak bildirilmiştir. Aynı zamanda, mutant p53/YAP/TEAD kompleksinin cicrPVT1 ifade seviyesini transkripsiyonel seviyede arttırdığı gösterilmiştir. Mutant p53/YAP/TEAD kompleksi, circPVT1'in türevlendiği PVT1'in transkripsiyonundaki promotör bölgesinden farklı, transkripsiyonel olarak daha aktif bir promotör tarafından düzenlenmesini sağlamıştır. PVT1 promotörü ayrıca, circPVT1'in ifadesinin transkripsiyonel seviyede kontrolünü sağlamaktadır (32). Buna ek olarak TP53 doğrudan uc.339'u düzenlemektedir. uc.339 direkt olarak TP53 tarafından susturulur ve uc.339, siklin E'nin (CCNE2) ifade seviyesinin artmasına, tümör büyümesine ve göçüne neden olan miR-339, miR-663b ve miR-95'in seçilime aracılık eder (33).

Tümör baskılayıcı genlerin aktivitesini engellemek için IncRNA ANRIL (antisense non-coding RNA in the INK4 locus) tarafından farklı bir aktivasyon yolağı etkinleşir. Baskılayıcı proteine bağlanmak için DNA ile yarışmak yerine ANRIL, PRC2'nin (polycomb repression complex 2) alt birimi olan SUZ12 (suppressor of zeste 12 homolog) ile etkileşime girer ve p15 (INK4B) ifadesinin baskılamak için kompleksi uyarır. Buna ek olarak, ANRIL'in ifade seviyesinin azalmasının p15 (INK4B)'in ifade seviyesini arttırdığı ve hücre çoğalmasını baskıladığı rapor edilmiştir (34). Glioma hücrelerinde ANRIL baskılanması ile hücre çoğalması, göçü ve invazyonunun baskılandığı ve PI3K/AKT ve mTOR yolaklarının etkisini yitirmesini sağlayan SIRT1'in miR-34a aracılı düşük ifadesiyle apoptozun baskıladığı gösterilmiştir (35). Ayrıca, üçlü negatif meme kanseri doku ve hücrelerinde ANRIL'in, miR-199a ile sünger (sponge) oluşturarak kanser oluşumunu teşvik ettiği bildirilmiştir (36).

İlk olarak fare NIH3T3 fibroblastlarında ifade seviyesi artmış olarak bulunan GAS5 (Growth Arrest-Specific 5) bilinen en yaygın tümör baskılayıcı IncRNA molekülüdür (37). Ayrıca GAS5, önemli biyolojik süreçlerde etkin rolleri olan ve bu IncRNA 
geninin intronik kısmında yerleşik olan birçok snoRNA'nın konak genidir. Buna ek olarak GAS5 bir ribobaskılayıcı olarak işlev görür. Bu molekül glukokortikoid reseptörlerinin DNA bağlama alanı ile etkileşir, bu nedenle bu reseptöre bağlanmak için genomdaki glukokortikoid tepki elemanları ile rekabet eder. Dolayısıyla cIAP2 (cellular inhibitor of apoptosis 2) dahil birçok ilişkili genin uyarılmasını baskılayarak apoptozun uyarılmasını sağlar (38).

\section{Hücre Ölümüne Karşı Direnç}

Normal hücrelerde apoptoz ile programlı hücre ölümü kanser gelişimine karşı doğal bir savunma mekanizmasıdır. Apoptotik mekanizma yukarı düzenleyici ve aşağı etkileyici bileşenlerden oluşmaktadır (7). Bu düzenleyiciler iki ana kola ayrılmaktadır. Bunlardan biri hücre dışı ölüm sinyallerini alan ve işleyen (örneğin, Fas ligand/ Fas almacını içeren dışsal apoptotik program) düzenleyicilerden oluşurken diğeri hücre içi kökenli çeşitli sinyalleri algılayan ve bütünleştiren (içsel apoptotik program) düzenleyicilerinden oluşmaktadır (39). Bu yolaklardan her biri, normal olarak latent proteazların aktivasyonuyla sonuçlanır (sırasıyla kaspaz 8 ve 9). Bu latent proteazların aktivasyonu apoptozun uygulanma aşamasından sorumlu etkileyici kaspazları içeren bir dizi proteoliz sürecini başlatır. Bu süreçte hücre komşu hücreler ve profesyonel fagositik hücreler tarafından aşamalı bir şekilde sindirilir. Apoptoz mekanizması pro-apoptotik ve anti-apoptotik BCL-2 ailesi proteinleri tarafından kontrol altında tutulur. Bcl-2, en yakın akrabaları (Bcl-xL, Bcl-w, Mcl1, A1) ile birlikte apoptoz baskılayıcısıdır. Bu apoptoz baskılayıcı proteinler büyük oranda iki proapoptotik tetikleyici proteini (Bax ve Bak) baskılayarak etki ederler. Bax ve Bak, antiapoptotik akrabaları tarafından baskıdan kurtulduğunda mitokondri dış zarının bütünlüğünü bozarak proapoptotik sinyal proteinlerinin salınmasına neden olur; bunlardan en önemlileri sitokrom c'dir. Salınan sitokrom c bir seri kaspaz aktivasyonunu başlatır. Bax ve Bak, BH3 motifleri olarak adlandırılan protein-protein etkileşim domainleri içerirler (39).

Yapılan çalışmalar, kanserde tedaviye yönelik önemli bir hedef olan BCL-2'nin 50'den fazla miRNA tarafından düzenlendiğini ve bu miRNA'ların büyük çoğunluğunun kanser ve apoptoz mekanizması ile ilişkili olduğunu göstermiştir. MiR-15a ve miR-16 insan kanserlerinde downregüle olduğu bildirilen ilk miRNA'lardır ve BCL-2 antiapoptotik proteinini hedeflemektedirler (40). BCL2 ailesinin diğer üyelerinin de birçok miRNA tarafından düzenlendiği hem endojen hem de ekzojen olarak doğrulanmıştır. Küçük hücreli olmayan akciğer kanserinde (NSCLC) BCL2'nin miR-206 ve miR-1290'nın doğrudan hedefi olduğu gösterilmiştir. Ayrıca, miR-1290 aracılığıyla BCL2'nin susturulmasının A549 akciğer kanseri hücrelerinde apoptotik etkiyi düzenlediği bildirilmiştir (41). NSCLC'de miR-206'nın ifade seviyesinin oldukça düşük olduğu gösterilmiştir. miR-206, BCL2 ve MET (MET proto-oncogene, receptor tyrosine kinase) seviyelerini azaltarak tümör baskılayıcı görev yapmaktadır (42). HOTAIR onkojenik bir IncRNA molekülüdür ve farklı kanser türlerinde prognostik bir biyobelirteç olarak kullanılabileceği gösterilmiştir. Birçok kanser türünde, HOTAIR kanser oluşumunda ve ilerlemesinde anahtar bir rol oynamaktadır (43).

Diğer taraftan, tümör gelişiminde kilit rol oynayan birkaçanormalliksensörütanımlanmıştır. Buanormallik sensörlerinden bir tanesi TP53 tümör baskılayıcı aracılığıyla işlev gören DNA hasar sensörüdür. TP53 DNA hasarı ve diğer kromozom anormallikleri olduğu durumlarda, Noxa, Puma ve BH3-only proteinlerinin ifadesini arttırarak apoptozu tetikler. Alternatif olarak, yetersiz sağ kalım faktörü sinyali (örneğin lenfositlerde interleukin-3 seviyesinin yetersiz olması veya epitel hücrelerinde insülin benzeri büyüme faktörü 1/2 [lgf1/2] seviyesinin yetersiz olması) Bim proteini aracılığıyla hücreyi apoptoza götürebilir. Ek olarak, Myc gibi onkoproteinlerin aşırı aktivitesini kapsayan diğer bir mekanizma ile de apoptozu tetikleyebilir $(7,39)$. Normal hücrelerin aksine kanser hücreleri apoptozu sınırlamak ve apoptozdan kaçmak için birçok yöntem geliştirmişlerdir. Bu yöntemlerden en iyi bilineni TP53 aktivitesinin kaybıdır. TP53 aktivitesinin kaybı, bu kritik DNA hasar sensörünü apoptozu tetikleyen devreden çıkarır. Bunun yanında, kanser hücreleri Bcl-2 ve Bcl$\mathrm{xL}$ gibi anti-apoptotik düzenleyici proteinlerin veya Igf1/2 gibi sağ kalım sinyallerinin ifadesinin artması, Bax, Bim, Puma gibi proapoptotik proteinlerin ifade seviyelerinin azalması gibi çeşitli mekanizmalarla apoptozun önüne geçebilirler. Dolayısıyla, programlı hücre ölümü kansere karşı doğal bir savunma mekanizması olarak görülmekte ve kanser tedavisi açısından büyük önem arz etmektedir $(7,39)$. Yapılan çalışmalar DNA hasarı ile uyarılan IncRNA PANDA (P21 associated ncRNA DNA damage activated)'nın transkripsiyon faktörü NF-YA (Nuclear Transcription Factor $Y$ Subunit Alpha) ile etkileşim göstererek trans etki ettiği ve pro-apoptotik genlerin ifade seviyelerini sınırlandırdığı gösterilmiştir (44).

\section{Ölümsüz Çoğalmaya Olanak Sağlama}

Kanser hücrelerinin makroskobik tümörleri 
oluşturabilmeleri için limitsiz ölümsüz çoğalmaya olanak sağlamaları gerekmektedir. Vücuttaki birçok normal hücre soyları belirli sayıda başarılı büyümebölünme döngüsü geçirirken, kanser hücreleri bu kurala uymayarak limitsiz bir şekilde çoğalabilirler. Normal hücrelerdebukuralın kontrolaltında tutulmasını sağlayan iki mekanizma vardır. Birincisi yaşlanma, ikincisi ise hücre ölümüne sebep olan kriz durumudur. Hücreler kültür ortamında çoğaltıldıklarında önce yaşlanma evresine girerler, daha sonra ise yaşlanma bariyerini aşan hücreler kriz evresine girerler ve bu durum hücre popülasyonundaki hücrelerin büyük çoğunluğunun ölümüne yol açar. Nadir durumlarda bazı hücreler yaşlanma ve kriz sonucu tetiklenen hücre ölümünden kaçarak limitsiz bir şekilde bölünme potansiyeli sergilerler (7).

Yapılan birçok çalışma, kromozomların uçlarını koruyan telomerlerin limitsiz çoğalmada merkezi bir rol oynadığını göstermektedir. Telomerler birçok ardışık hekzanükleotit tekrarlarından (TTAGGG) oluşurlar. Ölümsüz olmayan hücrelerde aşamalı olarak kısalırlar ve sonunda kromozomal DNA uçlarını uçtan uca füzyonlardan koruma yeteneklerini kaybederler. Bu tür füzyonlar kararsız disentrik kromozomlar üretir ve bu durum hücrenin yaşayabilirliğini tehdit eden karyotip karışıklığıyla sonuçlanır. Dolayısıyla, bir hücrede telomerik DNA'nın uzunluğu hücrenin kaç tane başarılı hücre bölünmesi geçireceğini belirlemektedir. Sonuç olarak, iyice kısalan telomerler kromozomal DNA uçlarını koruma yetisini kaybederek hücrenin kriz evresine girmesini tetikler (45). Telomeraz, telomerik DNA'nın uçlarına telomer tekrar bölümleri ekleyen özel bir DNA polimeraz enzimidir. Telomeraz aktivitesi ölümlü hücrelerde yok denilebilecek kadar azdır. Ancak, kanser hücreleri başta olmak üzere birçok ölümsüz hücrede fonksiyonel olarak anlamlı seviyelerde artış göstermektedir. Artmış telomeraz aktivitesi yaşlanma ve apoptoza karşı bir direnç oluşturmaktadır. Tersine, telomeraz aktivitesinin baskılanması telomerlerin kısalmasına sebep olarak yaşlanma ve hücre ölümü gibi hücre çoğalmasını baskılayan mekanizmaların tetiklenmesine sebep olmaktadır (45).

Telomerazı içeren ana yolak kritik olarak bir ncRNA'ya bağlıdır. Telomeraz holoenzimi, TERC (Telomerase RNA Component) veya TR (Telomerase RNA) olarak da bilinen bir RNA ve TERT (Telomerase Reverse Transcriptase) adı verilen bir ters transkriptaz olan bir protein bileşeninden oluşur (46). Telomerik RNA türler arasında dizilim ve boyut yönünden farklılık gösterebilmektedir. Telomer sentezi, ölümsüzleşme için gerekli TERC içerisinde küçük bir şablon bölgesinin TERT katalizli revers transkripsiyonunu içerir. TERC geninin ifadesinin çeşitli kanser türlerinde arttığı bildirilmiştir. Dolayısıyla, telomeraz aktivitesinin baskılanması kanser tedavisine yönelik önemli bir yöntem olarak öne çıkmıştır (46). Son yıllarda yapılan çalışmalar, TERC'in yanı sıra telomerler ile ilişkili başka ncRNA'ların da olduğunu ortaya koymuştur. Örneğin; TERRA (telomeric repeat-containing RNA) birçok subtelomerik bölgeden türevlenebilen bir ncRNA molekülüdür. TERRA telomerlerde yerleşiktir ve telomerik heterokromatin oluşumu ile ilişkilendirilmiştir (47). Elde edilen bulgular neticesinde TERRA'nın telomeraz enziminin doğrudan baskılayıcısı olduğu, tek tek veya tüm telomerlerde etkili olabilen ve telomerazın negatif düzenleyicisi olduğu düşünülmektedir (47). Buna ek olarak, miRNA'ların telomer uzunluğunun düzenlenmesinde görev alabilen moleküller olduğu bildirilmiştir. MiR155, miR-138 ve miR-34a,b,c'nin telomer uzunluğu ile ilişkili olduğu gösterilmiştir (48).

\section{Anjiyogenezin Tetiklenmesi}

Normal dokulara benzer şekilde tümör dokuları da besin ve oksijen almaya, metabolik atıkları ve karbondioksiti uzaklaştırmaya intiyaç duyarlar. Anjiyogenez ile oluşan tümör ilişkili damarlar bu intiyaçların karşılanmasını sağlarlar. Embriyogenez sonrasında damarlaşma büyük ölçüde inaktiftir. Yetişkinlerde, normal koşullarda anjiyogenez yara iyileşmesi ve menstural döngü gibi fizyolojik olaylarda geçici olarak aktif hale gelirken, tümör oluşumu sırasında hemen hemen her zaman aktiftir ve büyüyen neoplazinin beslenmesi için sürekli yeni damarlanmaların oluşmasına olanak sağlar (49). Tümör damarlaşması, gelişmemiş kılcal filizlenme, kıvrık ve aşırı damar dallanması, bozuk ve geniş damarlar, düzensiz kan akışı, mikro hemoraji, sızıntı ve anormal seviyedeki endotel hücre proliferasyonu ve apoptoz ile karakterizedir. Anjiyogenez, hem insan hem de hayvan deney modellerinde invaziv kanserlerin çok aşamalı gelişiminde şaşırtıcı derecede erken safhalarda uyarılır. Çeşitli organlarda ortaya çıkan premalign, noninvaziv lezyonlar, displaziler ve in situ karsinomların histolojik analizleri anjiyogenezin erken tetiklediğini ortaya çıkarmıştır.

Yapılan araştırmalar anjiyogenezin, anjiyogenezi tetikleyen ve baskılayan faktörlerin karşılıklı etkisi ile kontrol altında tutulduğunu göstermiştir. Bu anjiyogenik faktörlerden bazıları, vasküler endotel hücreleri tarafından sergilenen uyarıcı veya baskılayıcı hücre yüzeyi almaçlarına bağlanan sinyal proteinleridir. 
Anjiyogenez tetikleyicilerinin ve baskılayıcılarının iyi bilinen prototipleri sırasıyla vasküler endotel büyüme faktörü-A (VEGF-A) ve trombospondin-1 (TSP-1) 'dir. VEGF-A geni, embriyonik ve postnatal gelişim, endotel hücrelerinin homeostatik hayatta kalması ve yetişkinlikte çeşitli fizyolojik ve patolojik durumlarda yeni kan damarlarının oluşumunda rol oynayan ligandları kodlar. VEGF sinyal iletimi üç reseptör tirozin kinaz (VEGFR-1-3) tarafından gerçekleştirilir. VEGF gen ifadesi hipoksi ve onkogenik uyarılara karşı artabilir (50-51). Buna ek olarak, fibroblast büyüme faktörü (FGF) ailesinin üyeleri gibi diğer proanjiyogenik sinyallerin ifadesinin kronik olarak artması tümör anjiyogenezinin sürdürülmesine katkı sağlamaktadır (49). TSP-1, endotel hücreler üzerinde bulunan transmembran reseptörlere bağlanarak proanjiyogenik uyarıları baskılayıcı görev yapar (51).

Yapılan çalışmalar, TSP-1, anjiyostatin ve endostatinin endojen anjiyogenez baskılayıcıları olduklarını göstermiştir. Ayrıca, normal doku damarlaşmasında damarların dış kısmını sararak damar yapısına mekanik ve fizyoloji destek görevi yapan perisitlerin tümör damarlaşmasında düzgün yapılanmadığı ve böylelikle işlevsel normal damarlardan daha zayıf bir yapı oluştuğu yapılan çalışmalar ile gösterilmiştir (51). Buna ek olarak, makrofajlar, nötrofiller, mast hücreleri ve miyeloid progenitörler gibi birçok kemik iliği kaynaklı hücrenin patolojik anjigenezde önemli roller oynadığını göstermiştir. Bu hücreler, tümör dokularına sızarak anjiyogenezin devamlılığını sağlar ve bölgesel invazyonu hızlandırırlar (52). Anjiyogenez sadece protein kodlayan genlerde oluşan değişimlerle değil aynı zamanda ncRNA'lar tarafından da düzenlenebilen bir süreçtir. Yapılan çalışmalarda anjiyogenez ile ilişkilendirilmiş onlarca miRNA'nın olduğu gösterilmiştir. Bu miRNA'lar anjiyogenezin negatif düzenleyicileri olarak işlev görmektedirler (53). HUVEC (human umbilical vein endothelial cells) hücrelerinin Ang-1'e maruz kalması sonucunda olgun miR-103b, miR-330a-5p, miR-557, miR-575, miR-1287-5p ve miR-1468-5p ifadelerinin belirgin bir şekilde azalmasının tetiklendiği ve bu miRNA'ların endotel hücrelerin hayatta kalmasını, çoğalmasını, göçünü ve farklılaşmasını engellediği gösterilmiştir (53).

Uzun ncRNA'lar anjiyojenik süreçlerin düzenlenmesinde önemli fonksiyon göstermektedirler. HIF1a (hypoxia inducible factor $\alpha$ ) geninin 3' ucu ile komplementer bölge içeren doğal antisense transkript aHIF1, anjiyogenezde kritik rolleri olan HIF1a geninin ifadesini negatif yönde etkilemektedir (54). Yapılan araştırmalar, aHIF1'in birçok insan kanserleri ile ilişkili olduğunu ve özellikle meme kanserinde kötü prognoz ile ilişkilendirildiğini göstermektedir (55). Buna ek olarak, NOS3AS geninin karşı sarmalından sentezlenen doğal antisense transkript sONE endotel hücreler hariç birçok hücre türünde tanımlanmıştır. Tümörde, östrojen gibi tümör oluşumu teşvik edici ajanlar eNOS ifadesini uyarmaktadır ve birçok kanser tedavisini eNOS ifadesinin ve aktivitesinin etkilediği gösterilmiştir (56).

\section{İnvazyon ve Metastazın Etkinleşmesi}

Kanser hücrelerinin diğer önemli bir ayırt edici özelliği ise invazyon ve metastaz yaparak vücudun diğer bölgelerine yayılabilme yeteneklerinin olmasıdır. 2000'li yılların başlarında invazyon ve metastazın altında yatan mekanizma tam olarak anlaşılamamıştı. Ancak, daha sonra yapılan araştırmalar, kanser hücrelerinin invazyon ve metastaz yapabilmeleri için bir takım morfolojik değişim geçirmeleri ve diğer hücreler ve ekstraselüler matris (ECM) ile olan bağlantılarını değiştirmeleri gerektiğini göstermiştir (7). Şüphesiz bu süreçte meydana gelen değişikliklerin en iyi tanımlanmış olanlarından bir tanesi E-cadherin proteinin kaybıdır. E-cadherin, önemli bir hücrehücre adezyon molekülüdür. E-cadherin hücreler arası bağlantılar oluşturarak ve epitel hücrelerin bir araya gelerek epitel hücre tabakaları oluşturmalarına olanak sağlar. E-cadherinin artmış ifadesi invazyon ve metastazı baskılarken, E-cadherinin ifadesinin azalması bu fenotiplerin ilerlemesine neden olmaktadır. İnsan kanserlerinde E-cadherinin azalmış ifadesi ve mutasyonla aktivitesini kaybetmesi bu molekülün invazyonu ve metastazı baskılanmasındaki rolünü desteklemektedir (7).

Yapılan çalışmalarda, insan kanserlerinde hücre-hücre ve hücre-ECM adezyon moleküllerin ekspresyon seviyelerinde değişimler olduğu saptanmıştır. Örneğin, N-cadherin normal koşullarda göç eden nöronlarda ve organogenez sırasında mezenkimal hücrelerde ifade edilirken, birçok invazif kanserde de ifade edildiği rapor edilmiştir.

\section{Epitelyal Mezenkimal Geçiş (EMT)}

EMT kanser hücrelerinin invazyon ve metastazında önemli rol oynayan normal hücresel bir süreçtir. EMT programı, invazyon ve metastaz sırasında kanser hücreleri tarafından geçici olarak veya sürekli olarak farklı derecelerde aktive edilebilir. EMT embriyogenez sırasında görülen normal fizyolojik bir olaydır. Snail, Slug, Twist ve Zeb1/2'yi içeren bir dizi transkripsiyon faktörü seti, embriyogenez 
sırasında EMT ve ilgili göç süreçlerini düzenler. Yapılan deneysel kanser oluşum modellerinde, bu transkripsiyon faktörlerinin çeşitli malign tümör tiplerinde çeşitli kombinasyonlarda ifade edildiği gösterilmiştir. Kanser hücrelerinde meydana gelen bu değişimler hücreler arası bağlantı proteinlerinin kaybı (E-cadherin), matris yıkım enzimlerinin ifadesinin artması (metaloproteinazlar, kathepsin proteazlar), artmış hücre hareketliliği, apoptoza karşı direnç ve epitel hücre morfolojisinden mezenkimal hücre morfolojisine geçiş gibi kanser hücrelerinin invazyon ve metastaz yapabilmelerine olanak sağlayan önemli değişikliklere sebep olmaktadır (57). Kanser hücreleri invazyon ve metastaz sonrasında EMT programını tersine düzenleyerek mezenkimal epitelyal geçişi (MET) aktifleştirebilir. MET sonucu başka doku ve organlarda yeni tümör oluşumu görülür. Yeni oluşan ikincil tümörlerdeki bu kanser hücreleri primer tümörlerdeki EMT programına hiç girmeyen kanser hücreleri ile benzer bir histopatoloji sergiler. Ayrıca, kanser hücrelerinin düzenli bir EMT programından geçtiği fikri basit kalmaktadır; bunun yerine, birçok durumda, kanser hücreleri EMT programına yalnızca kısmen girebilir. Dolayısıyla, kanser hücreleri bazı epitelyal özelliklerini ifade etmeye devam ederken yeni mezenkimal özellikler kazanır (Şekil 2) $(7,57)$.

miR-200 ailesi, miR- 200a, miR- 200b, miR- 200c, miR- 141 ve miR- 429 içerir ve bu miRNA'ların uyuşum dizileri hedef gende aynı bölgeyi tanımaktadır. Yapılan çalışmalar bu miRNA ailesinin kanser invazyonu ve EMT ile ilişkili olduğunu göstermiştir (58). miR$200 \mathrm{c} / \mathrm{b}$, sırasıyla ZEB1/2 translasyonunun doğrudan baskılayıcısıdır. ZEB1 ve ZEB2 transkripsiyon faktörlerinin aşırı ifadesi, mide, pankreas ve yumurtalık kanserinin ilerleyen aşamalarında ortaya çıkmaktadır (58). ZEB1/2, E-cadherin promotöründeki E-kutularına bağlanarak EMT işlemini başlatır ve transkripsiyonunu bastırır. MiR- 200'ün aşırı ifade edilmesi, E- cadherin ifadesini uyarır ve iki ZEB'nin 3'- UTR'lerini doğrudan hedefleyerek Vimentin ifadesi baskılar ve böylece EMT veya MET'nin tersine çevrilmesinde önemli bir rol oynar (59). HULC'nin (Highly up- regulated in liver cancer) aşırı ifade edilmesi, önemli bir EMT uyarıcı transkripsiyon faktörü olan Snail'in ifade seviyesini düzenlediği gösterilmiştir (60). Ayrıca HULC, kanser ilerlemesinde önemli bir rol oynayan tümör invazyonu ve metastazı için bir gereksinim olan ZEB1 kaynaklı epitelyal-mezenkimal geçişe katkıda bulunur. HULC, hepatosüller kanser (HCC) hücrelerinde EMT'yi aktive etmek için mekanik olarak hareket eder ve HCC'de onkogen olarak devreye girer. Bu etki, miR-200a-

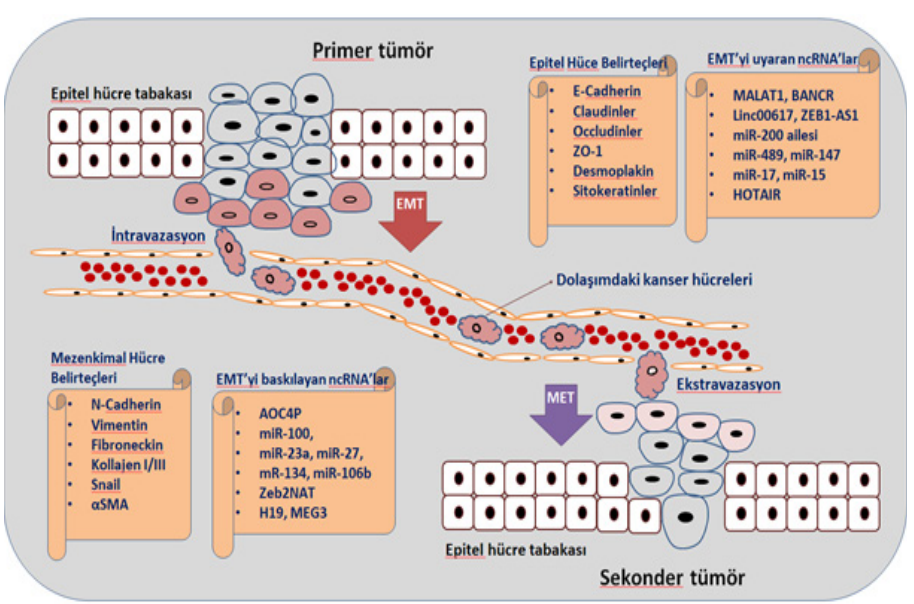

Şekil 2. Epitelyal-Mezenkimal Geçiş (EMT) ve Mezenkimal Epitelyal Geçiş (MET) mekanizmaları ve bu süreçlerde rol oynayan belirteçlerin gösterilmesi.

3p/ZEB1 sinyal yolağı aracılığıyla tümör ilerlemesi ve metastazını arttırmaktadır. Buna ek olarak, HOTAIR ile pozitif yönlü bir ilişkisi bulunan miR-23b3p'nin ZEB1 (zinc-finger E-box-binding homeobox 1) ile negatif yönlü ilişkisi olduğu gösterilmiştir. Yüksek HOTAIR seviyesi, miR-23b-3p'nin ifadesini baskılarken ZEB1'in ifade seviyesinin artmasını aracılık etmektedir. HOTAIR'in ZEB1 miR-23b-3p sponge aracılığıyla EMT'yi uyardığı ve metastazı teşvik ettiği bildirilmiştir (61). Ayrıca, NSCLC'de hasta sağ kalımı ve metastazı için prognostik faktör olarak tanımlanan MALAT1 birçok kanser türünde düzensiz ifade seviyesine sahip olduğu gösterilerek metastaz ile ilişkilendirilen IncRNA molekülüdür. Bu molekül çekirdek içinde bulunan beneklerde (speckles) yerleşik olan bir IncRNA'dır (62).

\section{Genom Kararsızlığı ve Mutasyon}

Yukarıda sayılan özelliklerin kazanılması, büyük oranda neoplastik hücrelerin genomlarında bir dizi değişikliğe, başka bir deyişle genomik kararsızlığa bağlıdır. Basit bir şekilde tasvir edecek olursak bazı mutant genotipler diğer hücre gruplarına karşı seçici bir avantaj sağlayarak baskın hale gelirler. Buna göre, çok basamaklı tümör ilerlemesi, mutant genotip tarafından tetiklenen başarılı bir klonal genişleme olarak tasvir edilebilir. Bazı klonal genişlemeler mutasyon kaynaklı olmayan değişikliklerden meydana gelebilir, örneğin tümör baskılayıcı genlerin etkisini kaybetmesi, DNA metilasyonu ve histon modifikasyonları gibi epigenetik mekanizmalar yoluyla da edinilebilir (63). Genomdaki bozuklukları denetleme sistemlerinin DNA'daki 
bozuklukları algılama ve çözmedeki olağanüstü kabiliyeti, her bir hücre soyunda kendiliğinden olan mutasyon oranlarının genellikle çok düşük olmasını sağlar. Genom denetleme sistemlerinde meydana gelen bozukluklar kanser hücrelerinin mutajenik ajanlara karşı aşırı duyarlı hale gelmelerine neden olarak mutasyon oranlarının artmasına yol açar. Buna ek olarak, normal olarak genom bütünlüğünü izleyen ve genetik olarak hasar gören hücreleri yaşlanmaya veya apoptoza zorlayan gözetim sistemlerinde meydana gelen bozukluklar mutasyonların birikimine neden olabilir. Tümör baskılayıcı p53 proteini genomda meydana gelen bozuklukların denetlenmesinde merkezi bir rol oynamaktadır ve bu özelliğinden dolayı "genomun koruyucusu" olarak adlandırımaktadır. Çeşitli miRNA'lar TP53 veya TP53 ile düzenlenmiş genleri farklı mekanizmalar yoluyla etkiler. Örneğin, miR-125b ve miR-504, TP53'ün 3'UTR kısmına bağlanarak doğrudan TP53'ü hedefler ve TP53 ifadesini negatif olarak düzenlerken, miR-29, PIK3R1 ve CDC42'yi hedefleyerek TP53'ün dolaylı olarakifade seviyesini arttırır ve miR-122, CCND1'i hedefleyerek p53 protein kararlıığını arttırır $(64,65)$. Buna ek olarak miR-34a'nın DNA hasar yanıtında önemli işlevleri olduğu gösterilmiştir ve yapılan yolak analizlerinde miR-34a'nın hücre döngüsünün ilerlemesi, apoptozun düzenlenmesi ve DNA onarımında görevli olan genlerin düzenlenmesinde aracılık edebileceği gösterilmiştir (66). Ayrıca, Poli (ADP-riboz) polimerazlar (PARP) ve topoizomerazlar, DNA onarımı, genomik kararsızlık ve apoptoz gibi bir takım hücresel süreçlerde rol oynamaktadır. PARP aktivitesi, tek iplikli DNA kopmalarının baz çıkarma onarımı için vazgeçilmezdir. Bu nedenle, PARP baskılanmasının yetersiz olması DNA hasar onarımı ve apoptoz ile sonuçlanacaktır. Ek olarak, PARP baskılanması DNA'ya zarar veren maddelerin sitotoksisitesini arttırır. Yapılan çalışmalarda PARP1'in miR-335 (67), ve miR-708-5p (68) gibi miRNA'lar ile düzenlendiğini göstermiştir.

Önceki çalışmalarda, genomun denetçileri olarak adlandırılan DNA denetleme sistemi bileşenlerinde meydana gelen birçok bozukluk rapor edilmiştir. DNA hasarının tespit edilmesi ve DNA tamir makinelerinin harekete geçirilmesi, hasar görmüş DNA'yı doğrudan onaran, mutajenik ajanları DNA hasar vermeden önce etkisini yitirme gibi çeşitli mekanizmalarda rol oynayan genlerde meydana gelen değişimler bu bozukluklardandır. Bu denetleyici genler tümör ilerlemesi sürecinde fonksiyonları kaybedilebileceği için tümör baskılayıcı genlere çok benzer davranırlar.
Tümör ile ilişkili genetik kararsızlığın bir başka önemli kaynağı birçok tümörde telomerik DNA kaybıdır. TelomerikDNA kaybı karyotipik kararsızlığa kromozom kararsızlığa ve buna bağlı olarak kromomozom segmentlerinin çoğalmasına ve delesyonuna sebep olmaktadır. Bu sebeple, kromozom uçlarının korunmasından sorumlu telomeraz enzimi önemli bir DNA denetleyicisidir. Kırılgan alanlar (fragile site), boşluklar veya kırılmalar oluşturma eğilimine sahip olan, düzenli bir şekilde yayılmış kromozomal lokuslardır. Bu kromozal lokusların kanser hücrelerini genomik kararsızlığa yatkın hale getirdiği ve bu bölgelerdeki değişikliklerin insan kanserinde nedensel bir rol oynadığı gösterilmiştir. Son zamanlarda miRNA genlerinin değişime eğilimli kırılgan bölgelerde, kırılgan olmayan bölgelere göre dokuz kat daha yüksek oranda olduğunu ortaya çıkarılmıştır. Calin ve ark. kırılgan bölgelerde yerleşik bazı miRNA'ların kanser gelişimi ve ilerlemesiyle ilişkili olduğunu bildirmişlerdir (69). Yapılan çalışmalarda birçok küçük delesyon bölgesinin tümör baskılayıcı özellik gösteren miRNA'ları içerdiği ve çoğalan bölgelerin ise onkogenik miRNA'ları içerdiği gösterilmiştir. Bu duruma en iyi örnek, KLL hastalarında 13q14.3'te lokusunda genellikle delesyona uğrayan $0,54 \mathrm{mb}$ uzunluğundaki miR-15a ve miR16-1 genlerinin kodlandığı bölge verilebilir. Ek olarak, meme ve akciğer kanserlerinde tümör baskılayıcı özellik gösteren miR-34a'yı kodlayan genin konumladığı ve sıklıkla delesyona uğramış bölge olan 11q23-q24 lokusu, birçok üretelyal kanserde delesyona uğramış olan, miR-24-1, miR-27b, miR-23b ve let-7a-1/let-7f-1 gibi önemli miRNA genlerinin konumlandığı 9q22.3 lokusu sıralanabilir (69).

Kromozom ayrılmasında temel işlevleri nedeniyle, sentromer proteinleri ve kohesin ağı, genomik kararlılık için kritik öneme sahiptir ve hücre bölünmesi sırasında sıkı bir şekilde düzenlenmelidir. Yapılan çalışmalarda bu proteinleri kodlayan genlerin bir IncRNA molekülü olan NORAD (noncoding RNA activated by DNA damage) tarafından düzenlenebileceği ortaya konulmuştur. NORAD silinmiş hücrelerde genomik kararlılığı korumak için görevli olan birçok genin ifade seviyesi önemli ölçüde azalma göstermiştir ve sonuç olarak bu hücrelerde yüksek oranda anöploidi görülmüştür (70). İlk olarak fare hücrelerinde tanımlanan NORAD, p53'e bağlı olarak DNA hasarı tarafından uyarılmış ve bu durum NORAD'ın DNA hasar cevabında bir rol oynayabileceğini göstermiştir (70).

Tümör Oluşumunu Teşvik Eden Inflamasyon 
Uzun yıllardır doğal ve kazanılmış bağışıklık sistemi hücrelerinin yoğun bir şekilde bazı tümör dokularına sızdığı bilinmektedir. Dolayısıyla, bu durum neoplastik olmayan normal dokularda eş zamanlı olarak inflamasyonun ortaya çıkmasına neden olmaktadır. Önceleri bu bağışıklık cevabı tümörü ortadan kaldırmak için gelişen doğal bir savunma mekanizması olduğu düşünülse de, sonraki çalışmalar bunun aslında bağışıklık sisteminden kaçmak için bir mekanizma olduğunu göstermiştir. Başka bir deyişle tümöre bağlı gelişen inflamasyon tümör gelişimini teşvik etmektedir. Tümör oluşumunu teşvik eden inflamasyon, tümör mikroçevresine bazı biyoaktif moleküller sağlayarak tümör gelişimine birçok yönden katkıda bulunabilir. Bu biyoaktif moleküller çoğalmanın devamlılığını sağlayan büyüme faktörleri, hücre ölümünü kısıtlayan hayatta kalma faktörleri, proanjiyogenik faktörler, anjiyogenez, invazyon ve metastazı hızlandıran ekstraselüler matrisi modifiye eden enzimler, EMT programını aktive eden tetikleyici sinyallerdir. Ayrıca, inflamatuar hücreler, aktif olarak reaktif oksijen türleri gibi mutajenik kimyasallar salgılayarak kanser hücrelerinde genetik bozukluğun artmasına sebep olurlar (7). Kodlanmayan RNA'lar ile ilişkili çalışmaların artmasıyla miRNA'ların tümör baskılayıcı/onkogenik özelliklerinin yanı sıra inflamatuvar geri besleme döngüsü aktivatörlerinin anahtar düzenleyicileri olarak görev yaptıkları ortaya çıkmıştır. miRNA aracılı geri bildirim döngüleri inflamatuvar sinyalleşme ile tetiklenir ve malign transformasyondahayatirolleroynar. Kolonkanserinde aşırı ifade edilen ve yüksek ifadesi kötü prognoz ve daha kısa genel sağ kalım ile ilişkilendirilen miR-21'in TGF 1, IFN ve IL-6 sinyalleşmesiyle uyarılabileceği ve kromatin kararsızlığı ile ilişkili aşağı yöndeki hedef mRNA'lar yoluyla kronik inflamasyon kaynaklı transformasyona aracılık edebileceği açıklanmıştır. Bunun yanı sıra, miR-155'in inflamasyonun pozitif düzenleyicisi olduğu gösterilmiştir. IFN- $\gamma$, TNF- $\alpha$ veya IL-1 $\beta$ gibi inflamatuvar sitokinler, transkripsiyonel olarak miR-155'i arttırdığı ve buna bağlı olarak JAK/ STAT1 yolağını uyardığı bildirilmiştir.

\section{Enerji Programının Yeniden Düzenlenmesi}

Neoplastik hastalığın temelini oluşturan kronik ve çoğunlukla kontrolsüz hücre çoğalması, sadece hücre çoğalmasının kontrolünün kaybı değil aynı zamanda hücre büyümesi ve bölünmesini sağlamak için enerji metabolizmasının yeniden düzenlenmesini gerektirir. Kanser hücreleri sürekli olarak çoğalmak için enerji metabolizmalarını değiştirirler. Aerobik koşullarda normal hücreler glikoliz ile glikozu işleyerek önce pirüvata ve daha sonra mitokontride karbon dioksite dönüştürürler. Anaerobik koşullar altında glikoliz tercih edilir ve nispeten az miktarda pirüvat oksijen tüketen mitokondriye gönderilir. Dolayısıyla, oksijen yokluğunda glikolize dayalı bir enerji metabolizması ortaya çıkar. Kanser hücrelerinin bu özelliği ilk olarak Otto Warburg tarafından ortaya konulmuştur. Warburg'a göre oksijen varlığında dahi, kanser hücreleri, enerji metabolizmasını büyük ölçüde glikoliz ile sınırlandırarak, glikoz metabolizmalarını ve dolayısıyla enerji üretimlerini yeniden programlayabilirler. Bu olay "aerobik glikoliz" veya Warburg etkisi olarak bilinmektedir. Enerji metabolizmasının böyle yeniden programlanması, mitokondriyal oksidatif fosforilasyona kıyasla, glikoliz tarafından sağlanan ATP üretimi yaklaşık 18 kat daha düşük verimliliğe sebep olur ve kanser hücrelerinin bu açığı kapatması gerekir (72). Bu açığın kapatılması adına kanser hücreleri birçok strateji geliştirmişlerdir. $\mathrm{Bu}$ stratejilerden bir tanesi kanser hücrelerinde GLUT1 gibi glikoz taşıyıcı moleküllerin ifade seviyelerinin artmasıdır (73). Kanser hücrelerinin bu aktif glikoz tüketimi kanserin tanısında önemli bir yer tutan ve tümör lokalizasyonu hakkında bilgi veren PET taramasının temelini oluşturmuştur. PET taramasında radyoaktif işaretli bir glikoz analoğu olan 18F-florodeoksiglukoz (FDG) kullanılmaktadır. Ayrıca, yapılan araştırmalar, glikoza dayalı enerji metabolizmasının aktif onkogenler (RAS, MYC) ve mutant tümör baskılayıcı genler (TP53) ile ilişkili olduğu gösterilmiştir (73).

Sitoplazmada gerçekleşen glikoliz olayında üç kararlı basamak bulunmaktadır. Bunlardan ilki glikoz6-fosfat (G6P) üretmek için heksokinaz (HK) ile glikozun fosforilasyonudur. Yaygın olarak ifade edilen HK1'e ek olarak, kanser hücreleri, fosforillenmiş glikozun sitoplazmada tutulduğundan Warburg etkisi için kritik olan HK2'yi aşırı ifade etmektedir. HK2 geninin 3' UTR bölgesi miR-497 için tahmini bağlanma bölgesine sahiptir ve osteosarkoma hücrelerinde HK2'nin yüksek ifade seviyesine karşın miR-497 düşük ifade edildiği gösterilmiştir. Bu durum, miR-497 ile moleküler sünger oluşturan PVT1 (Plasmacytoma Variant Translocation 1) IncRNA molekülünün ifadesinin artmasına neden olmaktadır. Dolayısıyla PVT1/miR-497 ekseni HK2'nin ifadeni düzenleyerek Warburg etkisine katkı sağladığı açıklanmıştır (74). Glikolizin ikinci kararlı basamağı ise, F6P'nin fofofruktokinaz 1 (PFK1) ile katalizlenmesiyle F1,6P dönüşümüdür. HCC hücrelerinde yüksek ifade seviyesine sahip olan TARDBP (TAT-activating 
regulatory DNA-binding protein) PFKP (platelet isoformof PFK1) ifade seviyesini uyararak glikolizi düzenlediği bildirilmiştir. MiR-520 ailesi TARDBP'nin aracılık ettiği glikolizin bir ara düzenleyicisi olarak rol oynamaktadır. TARDBP miR-520 ailesinin ifadesini bastırdığı ve buna bağlı olarak PFKP'nin protein seviyesinde ifadesinin engellendiği gösterilmiştir (75). Glikolizin son kararlı basamağı fosfoenolpiruvatı (PEP) piruvata dönüştürmek için piruvat kinazlar (PK'ler) tarafından katalizlenmesidir. PK fonksiyonunun zayıflaması düşük afiniteli dimerik pirüvat kinaz (PK) M2 ifadesi ile sağlanabiliyorken, PKM2 ve PKM1'in tetramerik formları normal hücrelerdeki fizyolojik PEP seviyelerinde fonksiyoneldir. PKM2'ye bağlanama bölgesi bulunan miR-133a ve miR-133b gibi miRNA moleküllerinin kanser hücrelerinde düzensiz ifade edilerek PKM2'yi modüle ettiği gösterilmiştir (76).

Glikolize olan bu bağımlılık, birçok tümörde işlev gören hipoksi koşulları altında daha çok ortaya çıkmaktadır. Hipoksi tepki sistemi, glikoz taşıyıcılarını ve glikolitik yolağının birden fazla enzimini upregüle etmek için pleiotropik olarak hareket eder (73). Hem Ras onkoproteini hem de hipoksi, bağımsız olarak, HIF1 $\alpha$ ve HIF2 $\alpha$ transkripsiyon faktörü seviyelerini bağımsız olarak artırabilir ve bu da glikolizin artmasına neden olur. İlginç bir şekilde bazı tümörlerde enerji üretim yolağında farklılık gösteren iki farklı tip hücre popülasyonunun bulunduğu saptanmıştır. Bir hücre popülasyonu laktat salgılayan glikoz bağımlı ("Warburg etkisi") hücrelerden oluşurken, diğer hücre popülasyonu komşu hücreler tarafından üretilen laktatı ana enerji kaynağı olarak kullanan hücrelerden oluşmaktadır. Bu iki popülasyon açıkça simbiyotik olarak işlev görür: Hipoksik kanser hücreleri, yakıt için glikoza bağımlıdır ve atık olarak laktat salgılarlar, daha iyi oksijen alabilen diğer hücreler ise bu atıkları ana enerji kaynağı olarak kullanırlar. Buna ek olarak, tümör dokularında normoksiden hipoksiye değişen oksijen alım durumu statik olmayıp zamana ve bölgeye bağlı olarak farklılıklar göstermektedir $(7,73)$. LincRNA-p21 ve HIF-1a, Warburg etkisine katkıda bulunan pozitif geri bildirim döngüsü oluşturmaktadır. Hipoksik koşullarda, GLUT1 ve LDHA'nın aşırı ifade edilmesiyle glukoz alımı ve laktat üretimi artmaktadır (77). LincRNA-p21'in hipoksiye cevap veren bir IncRNA molekülü olduğu ve hipoksiyle güçlendirilmiş glikoliz için gerekli olduğu gösterilmiştir. Hipoksi/HIF-la ile uyarılan lincRNA-p21, HIF-la ve VHL'yi bağlayabilir ve böylece VHL-HIF-1 $\alpha$ etkileşiminin bozulmasına aracılık eder. Bu ayrılma sonucunda VHL aracılı HIF1 $\alpha$ ubikitinizasyonunu zayıflatır ve HIF-1 $\alpha$ birikmesine neden olur. Dolayısıyla, hipoksi koşullarında glikolizi destekleyen HIF-1a ve lincRNA-p21 arasında pozitif bir geri besleme döngüsünün olduğu görülmektedir (77).

\section{Bağışıklık Sisteminden Kaçış}

Uzun yıllardır kabul gören immün gözetim (immune surveillance) teorisine göre hücreler ve dokular sürekli olarak bağışıklık sistemi tarafından gözetim altında tutulmaktadır. Dolayısıyla, immün gözetim sistemi yeni ortaya çıkan kanser hücrelerinin büyük çoğunluğunu ve gelişmekte olan tümörleri tanımak ve ortandan kaldırmak ile sorumludur. Bu mantığa göre, ortaya çıkan solid tümörler bağışıklık sistemi tarafından tanınmaktan ve immünolojik ölümden bir şekilde kaçmaktadırlar. Bazı kanserlerin bağışıklık sistemi baskılanmış bireylerde şaşırtıcı bir şekilde artış göstermesi tümörlerde bozuk bağışıklık cevabına kanıt olarak gösterilebilir. Ayrıca, son yıllarda yapılan araştırmalar bağışıklık sisteminin tümör oluşumunu ve ilerlemesini önemli bir şekilde önlediğini ortaya koymuştur. Ayrıca, genetik olarak bağışıklık sistemi yetmezliği olan farelerde kontrol farelere göre tümörlerin daha sık ortaya çıktığı ve/ veya daha hızlı büyüdüğü gözlemlenmiştir. Özellikle, CD8+ sitotoksik T lenfositleri, CD4+ Th1 yardımcı T hücreleri veya doğal öldürücü (NK) hücrelerin gelişimi veya fonksiyonunda meydana gelen bozuklukların her biri tümör insidansında belirgin artışlara yol açmıştır. Dahası, hem $\mathrm{T}$ hücrelerinde hem de NK hücrelerinde kombine immün yetmezliği olan farelerin kanser gelişimine daha yatkın olduğu gösterilmiştir. Bu sonuçlar, bağışıklık sisteminin doğal ve kazanılmış hücresel kollarının immün gözetim sistemine ve dolayısıyla tümörün ortadan kaldırılmasında önemli rollerinin olduğunu göstermiştir.

Onkogenik veya tümör baskılayıcı miRNA'lara ek olarak immun sistemi etkileyen miRNA'ların olduğuna daha önce de değinmiştik. İmmun sistem ile ilişkilendirilmiş miRNA'lar im-miRNA'lar olarak adlandırılmaktadır. İm-miR'ler de kendi içinde alt gruplara ayrılabilmektedir. Tümör baskılayıcı immiRNA'lar immünojeniteyi geliştirirken ve bağışıklık tepkilerini artırarak immün gözetimi teşvik ederken, onkojenik im-miRNA'ların immün baskılayıcı bir potansiyele sahip olduğu ve bağışıklık kaçışında rol oynadığı gösterilmiştir. Örneğin; miR-155, monokin sinyalizasyon veya CD16 aktivasyonu yoluyla NK hücrelerinde IFN- $\gamma$ üretiminde merkezi bir rol oynamaktadır. Bunun aksine, miR-155'in CD4+ T hücrelerinde IFN-y sinyalizasyonunu baskıladığı gösterilmiştir. Günümüze kadar yapılan çalışmalarda, 
IncRNA'ların immün yanıtın düzenlenmesinde önemli bir rol oynadığını ve immun hücrelerinin gelişimini düzenleyebileceği gösterilmiştir. HULC IncRNA'sının HBV'ye bağlı karaciğer sirozunda Treg hücre farklılaşmasını düzenlediği bildirilmiştir (79). LncRNA SNHG1'in ifade seviyesinin meme kanseri hastalarının CD4+ TIL hücrelerinde arttığını ve SNHG1 susturulmuş hücrelerde Foxp3 ve IL-10 ifade seviyesinin azaldığı gösterilmiştir. Buna ek olarak, miRNA-IncRNA etkileşimini gösteren veritabanlarında SNHG1'in miR-448 tarafından hedeflenebileceği öngörülmektedir. Bu bağlamda CD4+ TIL hücrelerinde SNHG1 ve miR-448 arasında negatif bir ilişki olduğu ve Treg hücrelerinin farklılaşmasında önemli olabilecekleri bildirilmiştir.

Sonuç olarak; Bu kapsamlı derleme çalışmasında kanserin ayırt edici özelliklerini kodlanmayan RNA ile birlikte ele alarak kanserin moleküler mekanizmasının anlaşılması adına yeni bir bakış açısı getirmeyi amaçladık. Protein kodlayan genlere ek olarak bu genlerin etkileşim içerisinde olduğu kodlanmayan RNA moleküllerinin belirlenmesi kanserin kompleks biyolojisinin anlaşılması adına umut vaat etmektedir. Gün geçtikçe tanımlanan kodlanmayan RNA moleküllerinin sayısı artmaktadır ancak bu RNA moleküllerinin işlevleri ve protein kodlayan genlerle ve birbirleri ile olan etkileşimlerinin anlaşılması adına yapılacak olan ileriki çalışmalara çok intiyaç vardır. Böylelikle, kanserin tanı ve tedavisine yönelik hedeflenmiş özgül kanser ilaçlarının geliştirilmesi daha mümkün olacaktır.

Çıkar Çatışması: Çalışmada herhangi bir çıkar çatışması yoktur.

Finansal Çıkar Çatışması: Çalışmada herhangi bir finansal çıkar çatışması yoktur.

Yazışma Adresi: Esra Bozgeyik, Namık Kemal Mahallesi, Kampüs Caddesi Namık Kemal Üniversitesi No:1, 59030 Süleymanpaşa, Tekirdağ, Türkiye

e-mail:gyk.esra@gmail.com

\section{KAYNAKLAR}

1. Consortium EP. Identification and analysis of functional elements in $1 \%$ of the human genome by the ENCODE pilot project. Nature 2007;447(7146):799.

2. International Human Genome Sequencing C. Initial sequencing and analysis of the human genome. Nature 2001;409(6822):860.

3. Kapranov P, Cheng J, Dike S, et al. RNA maps reveal new RNA classes and a possible function for pervasive transcription. Science 2007;316(5830):1484-8.

4. Calin GA, Croce CM. MicroRNA signatures in human cancers. Nat Rev Cancer 2006;6(11):857.
5. Chen LL, Carmichael GG. Long noncoding RNAs in mammalian cells: What, where, and why? Wiley Interdiscip Rev RNA 2010;1(1):2-21.

6. Hanahan D, Weinberg RA. The hallmarks of cancer. Cell 2000;100(1):57-70.

7. Hanahan D, Weinberg RA. Hallmarks of cancer: The next generation. Cell 2011;144(5):646-74.

8. Kastan MB, Bartek J. Cell-cycle checkpoints and cancer. Nature 2004;432(7015):316.

9. O'Leary B, Finn RS, Turner NC. Treating cancer with selective CDK4/6 inhibitors. Nat Rev Clin Oncol 2016;13(7):417.

10. Li Y, Liu J, Liu ZZ, et al. MicroRNA-145 inhibits tumour growth and metastasis in osteosarcoma by targeting cyclindependent kinase, CDK6. Eur Rev Med Pharmacol Sci 2016;20(24):5117-25.

11. Achari C, Winslow S, Ceder $Y$, et al. Expression of miR-34c induces $\mathrm{G} 2 / \mathrm{M}$ cell cycle arrest in breast cancer cells. BMC cancer 2014;14(1):538.

12. Zhao J-J, Lin J, Lwin T, et al. microRNA expression profile and identification of miR-29 as a prognostic marker and pathogenetic factor by targeting CDK6 in mantle cell lymphoma. Blood 2010;115(13):2630-9.

13. Zhu X, Ma SP, Yang D, et al. miR-142-3p Suppresses Cell Growth by Targeting CDK4 in Colorectal Cancer. Cell Physiol Biochem 2018;51(4):1969-81.

14. Zhang $\mathrm{Y}$, Zhang $\mathrm{H}$, Kang $\mathrm{H}$, et al. Knockdown of long noncoding RNA HOST2 inhibits the proliferation of triple negative breast cancer via regulation of the let-7b/CDK6 axis. Int J Mol Med 2019;43:1049-57.

15. Liu $Q$, Fu $H$, Sun $F$, et al. miR-16 family induces cell cycle arrest by regulating multiple cell cycle genes. Nucleic Acids Res 2008;36(16):5391-404.

16. Feng $\mathrm{T}$, Shao $\mathrm{F}, \mathrm{Wu} \mathrm{Q}$, et al. miR-124 downregulation leads to breast cancer progression via LncRNA-MALAT1 regulation and CDK4/E2F1 signal activation. Oncotarget 2016;7(13):16205-16.

17. Yang $X, X i a o Z$, Du $X$, et al. Silencing of the long non-coding RNA NEAT1 suppresses glioma stem-like properties through modulation of the miR-107/CDK6 pathway. Oncol Rep 2017;37(1):555-62.

18. Lemmon MA, Schlessinger J. Cell signaling by receptor tyrosine kinases. Cell 2010;141(7):1117-34.

19. Han S, Chen Y, Gao Y, et al. MicroRNA-218-5p inhibit the migration and proliferation of pterygium epithelial cells by targeting EGFR via PI3K/Akt/mTOR signaling pathway. Exp Eye Res 2018;178:37-45.

20. Wang J, Wang G, Li B, et al. miR-141-3p is a key negative regulator of the EGFR pathway in osteosarcoma. Onco Targets Ther 2018;11:4461-78.

21. Zhang PF, Wu J, Wu Y, et al. The IncRNA SCARNA2 mediates colorectal cancer chemoresistance through a conserved microRNA-342-3p target sequence. J Cell Physiol 2019;234(7):10157-65.

22. Hu J, Qian Y, Peng L, et al. Long noncoding RNA EGFR-AS1 promotes cell proliferation by increasing EGFR mRNA stability in gastric cancer. Cell Physiol Biochem 2018;49(1):322-34.

23. Davies MA, Samuels Y. Analysis of the genome to personalize therapy for melanoma. Oncogene 2010;29(41):5545.

24. Yuan TL, Cantley LC. PI3K pathway alterations in cancer: Variations on a theme. Oncogene 2008;27(41):5497.

25. Wang $Y$, Chen J, Chen X, et al. MiR-34a suppresses HNSCC growth through modulating cell cycle arrest and senescence. 
Neoplasma 2017;64(4):543-53.

26. Hirata $\mathrm{H}$, Hinoda $\mathrm{Y}$, Ueno $\mathrm{K}$, et al. MicroRNA-1826 targets VEGFC, beta-catenin (CTNNB1) and MEK1 (MAP2K1) in human bladder cancer. Carcinogenesis 2012;33(1):41-8.

27. Li YJ, Wang Y, Wang YY. MicroRNA-99b suppresses human cervical cancer cell activity by inhibiting the PI3K/AKT/mTOR signaling pathway. J Cell Physiol 2019;234(6):9577-91.

28. Li Z, Ma Z, Xu X. Long noncoding RNA MALAT1 correlates with cell viability and mobility by targeting miR223p in renal cell carcinoma via the PI3K/Akt pathway. Oncol Rep 2019;41(2):1113-21

29. Wang $X$, Dong $K$, Jin $Q$, et al. Upregulation of IncRNA FER1L4 suppresses the proliferation and migration of the hepatocellular carcinoma via regulating PI3K/AKT signal pathway. J Cell Biochem 2018.

30. Amit I, Citri A, Shay T, et al. A module of negative feedback regulators defines growth factor signaling. Nat Genet 2007;39(4):503.

31. Pang L, Li Q, Zhang $Y$, et al. Transcribed ultraconserved noncoding RNA uc. 160 acts as a negative regulator in gastric cancer. Am J Transl Res 2018;10(9):2822-33.

32. Verduci L, Ferraiuolo $M$, Sacconi $A$, et al. The oncogenic role of circPVT1 in head and neck squamous cell carcinoma is mediated through the mutant p53/YAP/TEAD transcriptioncompetent complex. Genome Biol 2017;18(1):237.

33. Vannini I, Wise PM, Challagundla KB, et al. Transcribed ultraconserved region 339 promotes carcinogenesis by modulating tumor suppressor microRNAs. Nat Commun 2017;8(1):1801.

34. Kotake $\mathrm{Y}$, Nakagawa T, Kitagawa K, et al. Long non-coding RNA ANRIL is required for the PRC2 recruitment to and silencing of $\mathrm{p} 15(\mathrm{INK} 4 \mathrm{~B})$ tumor suppressor gene. Oncogene 2011;30(16):1956-62.

35. Dong $X$, Jin Z, Chen $Y$, et al. Knockdown of long non-coding RNA ANRIL inhibits proliferation, migration, and invasion but promotes apoptosis of human glioma cells by upregulation of miR-34a. J Cell Biochem 2018;119(3):2708-18.

36. Xu ST, Xu JH, Zheng ZR, et al. Long non-coding RNAANRIL promotes carcinogenesis via sponging miR-199a in triplenegative breast cancer. Biomed Pharmacother 2017;96:1421.

37. Coccia EM, Cicala C, Charlesworth A, et al. Regulation and expression of a growth arrest-specific gene (gas5) during growth, differentiation, and development. Mol Cell Biol 1992;12(8):3514-21.

38. Armenia J, Fabris L, Lovat F, et al. Contact inhibition modulates intracellular levels of miR-223 in a p27kip1dependent manner. Oncotarget 2014;5(5):1185-97.

39. Hengartner MO. Apoptosis. Cell 2001;104(3):325-8.

40. Cimmino A, Calin GA, Fabbri $M$, et al. miR-15 and miR-16 induce apoptosis by targeting BCL2. Proc Natl Acad Sci U S A 2005;102(39):13944-9.

41. Kim KB, Kim K, Bae S, et al. MicroRNA-1290 promotes asiatic acidinduced apoptosis by decreasing BCL2 protein level in A549 nonsmall cell lung carcinoma cells. Oncol Rep 2014;32(3):1029-36.

42. Sun C, Liu Z, Li S, et al. Down-regulation of c-Met and Bcl2 by microRNA-206, activates apoptosis, and inhibits tumor cell proliferation, migration and colony formation. Oncotarget 2015;6(28):25533-74.

43. Gupta RA, Shah N, Wang KC, et al. Long non-coding RNA HOTAIR reprograms chromatin state to promote cancer metastasis. Nature 2010;464(7291):1071-6.

44. Hung $T$, Wang $Y$, Lin MF, et al. Extensive and coordinated transcription of noncoding RNAs within cell-cycle promoters. Nat Genet 2011;43(7):621.

45. Blasco MA. Telomeres and human disease: Ageing, cancer and beyond. Nat Rev Genet 2005;6(8):611.

46. Feng J, Funk WD, Wang S-S, et al. The RNA component of human telomerase. Science. 1995;269(5228):1236-41.

47. Redon $S$, Reichenbach $P$, Lingner J. The non-coding RNA TERRA is a natural ligand and direct inhibitor of human telomerase. Nucleic Acids Res 2010;38(17):5797-806.

48. Dinami $R$, Petti $E$, Sestito $R$, et al. microRNAs control the function of telomeres in cancer. RNA \& DISEASE 2014;1(1):e282.

49. Bergers G, Benjamin LE. Angiogenesis: Tumorigenesis and the angiogenic switch. Nature reviews cancer 2003;3(6):401.

50. Carmeliet P. VEGF as a key mediator of angiogenesis in cancer. Oncology 2005;69(Suppl. 3):4-10.

51. Lawler J. Thrombospondin-1 as an endogenous inhibitor of angiogenesis and tumor growth. J Cell Mol Med 2002;6(1):112.

52. Raza A, Franklin MJ, Dudek AZ. Pericytes and vessel maturation during tumor angiogenesis and metastasis. Am J Hematol 2010;85(8):593-8.

53. Sanchez V, Golyardi F, Mayaki D, et al. Negative regulation of angiogenesis by novel micro RNAs. Pharmacol Res 2018;139:173-81.

54. Thrash-Bingham CA, Tartof KD. aHIF: A natural antisense transcript overexpressed in human renal cancer and during hypoxia. J Natl Cancer I 1999;91(2):143-51.

55. Cayre A, Rossignol F, Clottes $E$, et al. aHIF but not HIF1a transcript is a poor prognostic marker in human breast cancer. Breast Cancer Res 2003;5(6):R223.

56. Xia Y, Krukoff TL. Estrogen induces nitric oxide production via activation of constitutive nitric oxide synthases in human neuroblastoma cells. Endocrinology 2004;145(10):4550-7.

57. Kalluri R, Weinberg RA. The basics of epithelial-mesenchymal transition. J Clin Invest 2009;119(6):1420-8.

58. Liu YN, Yin JJ, Abou-Kheir W, et al. MiR-1 and miR-200 inhibit EMT via Slug-dependent and tumorigenesis via Slugindependent mechanisms. Oncogene 2013;32(3):296.

59. Hill L, Browne G, Tulchinsky E. ZEB/miR-200 feedback loop: At the crossroads of signal transduction in cancer. Int $J$ Cancer 2013;132(4):745-54.

60. Yu X, Zheng H, Chan MTV, et al. HULC: An oncogenic long non-coding RNA in human cancer. J Cell Mol Med 2017;21(2):410-7.

61. Yang T, He X, Chen A, et al. LncRNA HOTAIR contributes to the malignancy of hepatocellular carcinoma by enhancing epithelial-mesenchymal transition via sponging miR-23b-3p from ZEB1. Gene 2018;670:114-22.

62. Ji P, Diederichs S, Wang W, et al. MALAT-1, a novel noncoding RNA, and thymosin beta4 predict metastasis and survival in early-stage non-small cell lung cancer. Oncogene 2003;22(39):8031.

63. Berdasco M, Esteller M. Aberrant epigenetic landscape in cancer: how cellular identity goes awry. Dev Cell 2010;19(5):698-711.

64. Fornari F, Gramantieri L, Giovannini C, et al. MiR-122/cyclin G1 interaction modulates p53 activity and affects doxorubicin sensitivity of human hepatocarcinoma cells. Cancer Res 2009;69(14):5761-7. 
65. Park S-Y, Lee JH, Ha M, et al. miR-29 miRNAs activate p53 by targeting p85a and CDC42. Nat Struct Mol Biol 2009;16(1):23.

66. Chang T-C, Wentzel EA, Kent OA, et al. Transactivation of miR-34a by p53 broadly influences gene expression and promotes apoptosis. Mol Cell 2007;26(5):745-52.

67. Luo Y, Tong L, Meng H, et al. MiR-335 regulates the chemoradioresistance of small cell lung cancer cells by targeting PARP-1. Gene 2017;600:9-15.

68. Guo P, Lan J, Ge J, et al. miR-708 acts as a tumor suppressor in human glioblastoma cells. Oncol Rep 2013;30(2):870-6.

69. Calin GA, Sevignani C, Dumitru CD, et al. Human microRNA genes are frequently located at fragile sites and genomic regions involved in cancers. Proc Natl Acad Sci U S A 2004;101(9):2999-3004.

70. Lee S, Kopp F, Chang T-C, et al. Noncoding RNA NORAD regulates genomic stability by sequestering PUMILIO proteins. cell 2016;164(1):69-80.

71. Kutty RK, Nagineni CN, Samuel W, et al. Inflammatory cytokines regulate microRNA-155 expression in human retinal pigment epithelial cells by activating JAK/STAT pathway. Biochem Biophys Res Commun 2010;402(2):3905.

72. House SW, Warburg O, Burk D, et al. On respiratory impairment in cancer cells. Science 1956;124(3215):267-72.

73. Jones RG, Thompson CB. Tumor suppressors and cell metabolism: A recipe for cancer growth. Genes Dev
2009;23(5):537-48.

74. Song J, Wu X, Liu F, et al. Long non-coding RNA PVT1 promotes glycolysis and tumor progression by regulating miR-497/HK2 axis in osteosarcoma. Biochem Biophys Res Commun 2017;490(2):217-24.

75. Park Y-Y, Kim S-B, Han HD, et al. Tat-activating regulatory DNA-binding protein regulates glycolysis in hepatocellular carcinoma by regulating the platelet isoform of phosphofructokinase through microRNA 520. Hepatology 2013;58(1):182-91.

76. Wong TS, Liu XB, Chunga-Wai Ho A, et al. Identification of pyruvate kinase type $\mathrm{M} 2$ as potential oncoprotein in squamous cell carcinoma of tongue through microRNA profiling. Int J Cancer 2008;123(2):251-7.

77. Yang $\mathrm{F}$, Zhang $\mathrm{H}$, Mei $\mathrm{Y}$, et al. Reciprocal regulation of HIF1a and lincRNA-p21 modulates the Warburg effect. Mol Cell 2014;53(1):88-100.

78. Banerjee A, Schambach F, DeJong CS, et al. Micro-RNA-155 inhibits IFN-gamma signaling in CD4+ T cells. Eur J Immunol 2011;40(1):225-31.

79. Zhao J, Fan $\mathrm{Y}$, Wang $\mathrm{K}$, et al. LncRNA HULC affects the differentiation of Treg in HBV-related liver cirrhosis. Int Immunopharmacol 2015;28(2):901-5.

80. Pei $X$, Wang $X$, Li $H$. LnCRNA SNHG1 regulates the differentiation of treg cells and affects the immune escape of breast cancer via regulating miR-448/IDO. Int J Biol Macromol 2018;118(Pt A):24-30. 